\title{
Pembiayaan Mikro BRI Syariah: Upaya Pemberdayaan dan Peningkatan UMKM oleh BRI Syariah Cabang Kendari
}

\author{
Muhamad Turmudi \\ Fakultas Ekonomi dan Bisnis Islam IAIN Kendari \\ Email: mturmudi76@gmail.com
}

\begin{abstract}
Understanding of micro, small and medium enterprises is based on indicators (1) the amount of wealth such as cash, supplies, land, machinery for production (2) the amount of investment that is considered as working capital (3) total sales in a year (4) total number of employees.

Micro Business Financing BRI Syariah is a business financing product intended for middle class people who have micro, small and medium enterprises to meet the needs/capital increase. in an effort to increase Micro, Small and Medium Enterprises in Kendari City, BRI Syariah has three financing products for Micro, Small and Medium Enterprises; (1) Micro 25iB; is a product without collateral financing, the ceiling of Rp. 5juta to Rp. 25juta (2) Micro 75iB; is a financing product with collateral, the ceiling of Rp. 10juta to Rp. 75M (3) Micro 500iB; is a financing product with collateral, the ceiling of Rp.> 75juta to Rp. 500 million.
\end{abstract}

Keywords: Micro, Small and Medium Enterprises, BRI Syariah Financing, Micro 25iB, Micro 75iB, Micro 500iB

\begin{abstract}
Abstrak
Pemahaman mengenai usaha mikro, kecil dan menengah berdasarkan pada indikator (1) jumlah kekayaan seperti uang tunai, persediaan, tanah, mesin untuk produksi (2) jumlah penyertaan yang dianggap sebagai modal kerja (3) jumlah total penjualan dalam setahun (4) jumlah pegawai.

Pembiayaan Usaha Mikro BRI Syariah merupakan produk pembiayaan usaha yang diperuntukkan bagi masyarakat menengah yang memiliki usaha mikro, kecil dan menengah guna memenuhi kebutuhan/penambahan modal. Dalam upaya peningkatan UMKM di Kota Kendari, BRI Syariah memiliki tiga produk pembiayaan bagi UMKM; (1) Mikro 25iB; merupakan produk pembiayaan tanpa agunan, besaran plafon Rp. 5juta s/d Rp. 25juta (2) Mikro 75iB; merupakan produk pembiayaan dengan agunan, besaran plafon Rp. 10juta s/d Rp. 75juta (3) Mikro 500iB; merupakan produk pembiayaan dengan agunan, besaran plafon Rp. $>75 j u t a ~ s / d ~ R p .500 j u t a$.
\end{abstract}

Kata Kunci: Usaha Mikro, Kecil dan Menengah (UMKM), Pembiayaan BRI Syariah, Mikro 25iB, Mikro 75iB, Mikro 500iB 


\section{A. Pendahuluan}

Bank sebagai lembaga keuangan secara spesifik berfungsi sebagai agent of trust, agent of development, serta agent of services. (Triandaru, Sigit dan Budisantoso, 2006, 16) Sebagai agent of trust, dalam rangka menghimpun dana dari masyarakat yang surplus dana dalam bentuk simpanan kemudian menyalurkannya pada masyarakat yang memerlukan dana dalam bentuk pembiayaan tentulah sangat membutuhkan kepercayaan (trust) dari masyarakat. Masyarakat percaya bahwa uang yang disimpan tidak akan disalahgunakan, akan dikelola dengan baik sehingga bank tidak akan bangkrut, dan pada saat tertentu masyarakat akan dapat menarik kembali simpanannya di bank. Begitupun bank dalam menyalurkan dananya percaya bahwa debitur tidak akan menyalahgunakan pinjamannya, dapat mengelola dana pinjaman dengan baik serta bank percaya bahwa debitur memiliki niat baik untuk mengembalikan pinjaman beserta kewajiban lainnya pada saat jatuh tempo. Untu itu, bank merupakan lembaga keuangan yang berfungsi sebagai perantara keuangan antara pihak yang berkelebihan dana dan pihak yang kekurangan dana, sehingga bank menerima simpanan uang dari masyarakat dan kemudian menyalurkannya kembali dalam bentuk kredit (Sinungan, 2000, 6) atau pembiayaan pada istilah perbankan syariah. Sebagai lembaga penghimpun dan penyalur dana, tugas tersebut sangat diperlukan untuk kelancaran kegiatan perekonomian disektor riil, sehingga memungkinkan masyarakat untuk berinvestasi, distribusi dan konsumsi yang berimbas pada kegiatan pembangunan perekonomian masyarakat. Sehingga bank berperan sebagai agent of development yang bertujuan menunjang pelaksanaan pembangunan nasional dalam rangka meningkatkan pemerataan, pertumbuhan ekonomi dan stabilitas nasional kearah peningkatan kesejahteraan rakyat banyak. (Djumhana, 2000,3)

Selain melakukan kegiatan penghimpunan dan penyaluran dana, bank juga memberikan penawaran jasa-jasa perbankan kepada masyarakat antara lain berupa jasa pengiriman uang, jasa penitipan barang berharga, jasa pemberian jaminan bank, serta jasa lainnya sehingga bank merupakan agent of services.

Sistem perbankan Islam sudah seharusnya menjadi sarana pendukung untuk mewujudkan tujuan dari sistem sosial dan ekonomi Islam, oleh karenanya sistem 
perbankan Islam diharapkan memiliki tujuan dan berfungsi sebagai berikut:

1. Kemakmuran ekonomi yang meluas dengan tingkat kerja yang penuh dan tingkat pertumbuhan ekonomi yang optimum (economic well-being with full employment and optimum rate ofeconomic growth);

2. Keadilan sosial-ekonomi dan distribusi pendapatan dan kekayaan yang merata (socio-economic justice and equitable distribution of income and wealth);

3. Stabilitas nilai uang untuk memungkinkan alat tukar tersebut menjadi suatu unit perhitungan yang terpercaya, standar pembayaran yang adil dan nilai simpan yang stabil (stability in the value of money);

4. Mobilisasi dan investasi tabungan bagi pembangunan ekonomi dengan caracara tertentu yang menjamin bahwa pihak-pihak yang berkepentingan

5. mendapatkan bagian pengembalian yang adil (mobilisationof savings);

6. Pelayanan efektif atas semua jasa-jasa yang biasanya diharapkan dari sistem perbankan (effective other services). (Capra, 2000)

Peran perbankan syariah dalam mengembangkan usaha masyarakat terutama pada usaha mikro adalah dengan berpartisipasi memberikan pembiayaan kepada masyarakat untuk mengembangkan usahanya, baik usaha perorangan maupun usaha dalam bentuk kelompok, dengan harapan pertumbuhan dan perkembangan ekonomi masyarakat dari tahun-ketahun terus mengalami peningkatan. Oleh karenanya, perbankan syariah terus mensupport agar nasabah yang mengambil pembiayaan usaha mikro dapat terus mengalami peningkatan perekonomian.

BRI Syariah yang merupakan salah satu lembaga keuangan yang memiliki program pembiayaan tentunya sangat mendukung akan perkembangan para pengusaha mikro, dukungan tersebut direalisasikan dengan mengeluarkan sebuah produk yang berupa pembiayaan bagi para pengusaha mikro dengan yang diberi nama Unit Mikro BRI Syariah iB yang bertujuan untuk kebutuhan tambahan modal ataupun investasi. Dengan adanya program pembiayaan tersebut para pengusaha mikro dapat tambahan pinjaman modal sehingga bisa mengembangkan usahanya.

\section{B. Kerangka Teori}

\section{Pembiayaan}




\section{a. Pengertian Pembiayaan}

Pembiayaan diartikan sebagai pendanaan yang dilakukan oleh lembaga keuangan, pembiayaan merupakan pendanaan yang dikeluarkan lembaga perbankan untuk mendukung investasi, konsumsi dan produksi yang ditujukan kepada nasabah. Pembiayaan merupakan penyediaan uang atau tagihan yang dapat dipersamakan berdasarkan persetujuan atau kesepakatan antara bank dengan pihak lain yang mewajibkan pihak yang dibiayai untuk mengembalikan uang atau tagihan tersebut setelah jangka waktu yang tertentu dengan imbalan atau bagi hasil. (UU No. 10, 1998, bab I, pasal 1) Secara teknis bank memberikan pendanaan atau pembiayaan untuk mendukung investasi atau berjalannya suatu usaha yang telah direncanakan antara kedua belah pihak dengan kesepakatan bagi hasil di dalamnya.

Kegiatan pembiayaan konsumen dalam syari'at Islam dapat dipandang sebagai perbuatan murabahah (pengembangan dari murabahah). (Lubis, 2004, 109) Dalam kegiatan pembiayaan konsumen, bank syariah mengadakan pembelian atas barang-barang yang dibutuhkan oleh konsumen. Selanjutnya menjual kembali barang yang dimaksud kepada konsumen dengan harga yang berbeda sesuai dengan kesepakatan. Perbedaan harga pembelian dan harga penjualan yang dilakukan oleh bank syari'ah ini kemudian disebut dengan marjin atau keuntungan.

Konsep pembiayaan pada bank syariah tidak benar-benar berbeda dengan konsep kredit pada bank konvensional, yang menjadi perbedaan antara kredit yang diberikan bank konvensional dengan pembiayaan yang diberikan oleh bank syariah adalah terletak pada keuntungan yang diharapkan. Bagi bank konvensional keutungan yang diperolah melalui bunga sedangkan bank syariah berupa imbalan atau bagi hasil. (Kasmir, 2005, 73)

\section{b. Unsur-Unsur Pembiayaan}

Setiap pemberian pembiayaan, jika dijabarkan secara mendalam mengandung beberapa arti yang meliputi unsur-unsur sebagai berikut:

1) Kepercayaan yaitu diberikan kepada debitur baik dalam bentuk uang, jasa maupum barang akan benar-benar dapat diterima kembali oleh bank dalam jangka waktu yang telah ditentukan.

2) Kesepakatan; Kesepakatan ini dituangkan dalam satu perjanjian 
diamana masing-masing pihak menandatangani hak dan kewajiban. Kesepakatan penyaluran pembiayaan dituangkan dalam akad pembiayaan yang ditandatangani oleh kedua belah pihak, yaitu bank dengan nasabah.

3) Jangka waktu; Setiap pembiayaan yang diberikan mempunyai jangka waktu masing-masing sesuai dengan kesepakatan. Jangka waktu ini mencangkup waktu pengambilan pembiayaan yang telah disepakati. Hampir dapat dipastikan bahwa tidak ada pembiayaan yang tidak memiliki jangka waktu.

4) Resiko; Dalam memberikan pembiayaan kepada perusahaan, bank tidak selamanya mendapatkan keuntungan, bank juga bisa mendapat risiko kerugian. Seperti ketika terjadinya side streaming, lalai dan kesalahan yang sengaja, maupun penyembunyian keuntungan nasabah. (Antonio, 2001, 49) Suatu resiko ini muncul karena ada tenggang waktu pembiayaan maka besar resiko tidak tertagih, demikian pula sebaliknya.

5) Balas jasa; Merupakan keuntungan atas pemberian suatu pembiayaan atau jasa tersebut yang kita kenal dengan bagi hasil. Balas jasa dalam bentuk bagi hasil ini dan biaya administrasi ini merupakan keuntungan bank.

\section{c. Tujuan dan fungsi pembiayaan}

Secara umum tujuan pembiayaan dibedakan menjadi dua jenis, yaitu pembiayaan untuk tingkat Makro dan pembiayaan tingkat Mikro. Secara makro pebiayaan bertujuan untuk:

1) Meningkatkan ekonomi umat artinya masyarakat yang tidak mendapatkan akses secara ekonomi, dengan adanya pembiayaan mereka dapat melakukan akses ekonomi. Dengan demikian dapat meningkatkantaraf ekonominya.

2) Tersedianya dana bagi peningkatan usaha, artinya untuk mengembangkan usaha membutuhkan dana tambahan. Dana tambahan ini dapat diperoleh melalui aktifitas pembiayaan. Pihak yang surplus dana menyalurkan pada pihak yang minus dana, sehingga dapat tergulirkan.

3) Meningkatkan produktifitas, artinya adanya pembiayaan memberikan peluang bagi masyarakat usaha manpu meningkatkan daya produksinya, sebab 
upaya produksi tidak akan dapat jalan tanpa adanya dana.

4) Membuka lapangan kerja baru, artinya dengan dibukaya sektor-sektor usaha melalui penambahan dana pembiayaan, maka sektor usaha tersebut akan menyerap tenaga kerja. Hal ini berarti manambah atau membuka lapangan kerja baru. (Muhammad, 2005, 17)

Selain pembiayaan makro, terdapat pembiayaan secara mikro yang diperuntukan kepada masyarakat atau pelaku usaha dengan tujuan sebagai berikut:

a) Upaya memaksimalkan laba, artinya: setiap usaha yang dibuka memiliki tujuan tertinggi, yaitu menghasilkan laba usaha. Setiap pengusaha menginginkan mampu mencapai laba maksimal. Untuk dapat menghasilkan. Laba maksimal maka mereka perlu dana yang cukup.

b) Pendayagunaan sumber ekonomi, artinya sumber daya ekonomi dapat dikembalikan dengan melakukan mixing antara sumber daya alam dengan sumber daya manusia serta sumber daya modal. Jika sumber daya alam dan dan sumber daya manusianya dan sumber modalnya tidak ada, maka diperlukan pembiayaan pada dasarnya dapat meningkatkan daya guna sumber-sumber daya ekonomi.

c) Penyaluran kelebihan dana, artinya: dalam kehidupan masyarakat ada pihak yang memiliki kelebihan sementara ada yang lain ada pihak yang kekurangan. Dalam kaitannya dengan masalah dana, maka mekanisme pembiayaan dapat menjadi jembatan dalam penyeimbangan dan penyaluran kelebihan dana dari pihak yang kelebihan (surplus) kepada pihak yang kekurangan(minus) dana. (Muhammad, 2005, 17)

\section{Usaha Mikro, Kecil, Dan Menengah}

\section{a. Pengertian}

Usaha mikro merupakan usaha informal yang memiliki asset, modal, omzet yang amat kecil, sehingga jenis komoditi usahanya sering berganti, tempat usaha kurang tetap, tidak dapat dilayani oleh perbankan dan umumnya tidak memiliki legalitas usaha. Sedangkan usaha kecil menunjuk kepada kelompok usaha yang lebih baik daripada itu, tetapi masih memiliki sebagian ciri tersebut (Amalia, 2009 : 16) oleh karena dalam kehidupan ekonomi sehari-hari, usaha mikro dan usaha kecil mudah dikenali dan mudah dibedakan dari usaha besar secara kualitatif. (Amalia, 2009, 41) 
Usaha kecil merupakan kegiatan ekonomi rakyat yang berskala kecil memiliki kekayaan paling banyak Rp. 200.000.000, tidak termasuk tanah dan bangunan tempat usaha atau memiliki hasil penjualan tahunan paling banyak Rp. 1.000.000.000,-..(Hafsah, 2000, 10)

Departemen Perindustrian dan Perdagangan yang membagi usaha kecil menjadi dua kelompok yaitu (1) Industri kecil adalah usaha industri yang memiliki investasi peralatan kurang dari Rp.700.000.000,-, investasi per tenaga kerja maksimum Rp.625.000,-, jumlah pekerja dibawah 20 orang serta asset dalam penguasaannya tidak lebih dari $\mathrm{Rp}$. 100.000.000,- (2) Perdagangan kecil adalah usaha yang bergerak dibidang perdagangan dan jasa komersial yang memiliki modal kurang dari Rp. 80.000.000,- dan perusahaan yang bergerak dibidang usaha produksi atau industri yang memiliki modal maksimal Rp. 200.000.000,(Amalia, 2009, 48)

M. Kwartono Adi memberikan kriteria pada usaha kecil adalah (l) memiliki kekayaan bersih paling banyak Rp. 200.000.000 (dua ratus juta rupiah), tidak termasuk tanah dan bangunan tempat usaha, (2) memiliki hasil penjualan tahunan paling banyak Rp. 1.000.000.000 (satu miliar rupiah), (3) milik Warga Negara Indonesia, (4) berdiri sendiri, bukan merupakan anak perusahaan atau cabang perusahaan yang dimiliki, dikusai, atau berafiliasi baik langsung maupun tidak langsung dengan usaha menengah atau usaha besar, (5) berbentuk usaha perorangan, badan usaha yang tidak berbadan hukum, atau badan usaha yang berbadan hukum, termasuk koperasi (Adi, 2007, 12), Termasuk dalam kategori usaha kecil antara lain usaha yang dijalankan oleh pasangan suami istri, seperti warung makan atau toko kecil disekitar perumahan (Nitisusastro, 2009, 52)

Untuk lebih memahami pengertian usaha mikro dan kecil dapat dibedakan berdasarkan indikator sebagai tolak ukur yang biasa digunakan antara lain (l) mengenai jumlah kekayaan, seperti uang tunai, persediaan, tanah, mesin untuk produksi dan sumber daya lainnya yang dimiliki, (2) jumlah besarnya penyertaan yang dianggap sebagai modal kerja, (3) jumlah total penjualan dalam setahun, (4) jumlah pegawai yang dipekerjakan berdasarkan jenis dan sifat usaha yang dijalani. (Nitisusastro, 2009, 37). 
Masalah yang biasanya dialami oleh UKM adalah sebagai berikut:

1) Permodalan; (1) Modal kecil sehingga sulit untuk memenuhi pesanan (2) Sulit mendapatkan kredit dari bank (3) Kurang mampu mengadakan perencanaan, pencatatan dan pelaporan, serta tidak dapat membuat neraca/laporan rugi laba Tercampurnya antara keuangan perusahaan dengan keluarga.

2) Pemasaran; (1) Kurang dapat melihat peluang pasar/salera pesanan (2) Akses terhadap imformasi pasar kurang (3) Terbatasnya tempat pemasaran (4) Kemampuan negoisasi yang lemah, sehingga berakibat kerugian pada sistem pembayaran dan perjanjian kontrak (5) Kurang kerjasama dengan perusahaan besar, sesame UKM, pihak luar negeri terutama dalam hal promosi (6) Kurang mampu merancang strategi bisnis.

3) Produksi/Teknologi; (1) Kurangnya pengetahuan tentang bagaimana memproduksi barang yang barkualitas, efisien dan diserahkan tepat waktu (2) Tidak ada transfer teknologi dari usaha besar (3) Tidak melakukan riset dan pengembangan (4) Tidak mengerti pentingnya kerjasama dengan pihak supplier (5) Tidak adanya proses perbaikan yang berkesinambungan.

4) Sumber Daya Manusia; (1) Pendidikan rendah (2) Rendahnya jiwa wirausaha (3) Keahlian terbatas (4) Rendahnya produktifitas pekerja (5) Tidak ada pembagian kerja.

5) Pemerintah; (1) Kurangnya dukungan dengan berbagai kebijakan yang berpihak pada UKM (2) Kurangnya menciptakan lingkungan usaha yang kondusif. (Adi, 2007, 4)

b. UMKM dalam UU RI Nomor 20 Tahun 2008

Usaha Mikro merupakan usaha produktif milik orang perorangan dan/atau badan usaha perorangan (UU No. 20, 2008, bab I, Pasal 1) yang memiliki kekayaan bersih paling banyak Rp. 50.000.000,00 (lima puluh juta rupiah) tidak termasuk tanah dan bangunan tempat usaha atau memiliki hasil penjualan tahunan paling banyak $\mathrm{Rp}$. 300.000.000,00 (tiga ratus juta rupiah). (UU No. 20, 2008, bab IV, pasal 6)

Usaha Kecil merupakan usaha ekonomi produktif yang berdiri sendiri, yang dilakukan oleh orang perorangan atau badan usaha yang bukan merupakan anak perusahaan atau bukan cabang 
perusahaan yang dimiliki, dikuasai, atau menjadi bagian baik langsung maupun tidak langsung dari Usaha Menengah atau Usaha Besar (UU No. 20, 2008, bab I, pasal 1) yang memiliki kekayaan bersih lebih dari Rp. 50.000.000,- (lima puluh juta rupiah) sampai dengan paling banyak Rp. 500.000.000,-(lima ratus juta rupiah) tidak termasuk tanah dan bangunan tempat usaha; atau memiliki hasil penjualan tahunan lebih dari Rp. 300.000.000,- (tiga ratus juta rupiah) sampai dengan paling banyak Rp. 2.500.000.000,- (dua milyar lima ratus juta rupiah). (UU No. 20, 2008, bab IV pasal 6)

Usaha Menengah merupakan usaha ekonomi produktif yang berdiri sendiri, yang dilakukan oleh orang perorangan atau badan usaha yang bukan merupakan anak perusahaan atau cabang perusahaan yang dimiliki, dikuasai, atau menjadi bagian baik langsung maupun tidak langsung dengan Usaha Kecil atau Usaha Besar (UU No. 20, 2008, bab I pasal 1) dengan jumlah kekayaan bersih lebih dari Rp. 500.000.000,- (lima ratus juta rupiah) sampai dengan paling banyak Rpl0.000.000.000,- (sepuluh milyar rupiah) tidak termasuk tanah dan bangunan tempat usaha; atau memiliki hasil penjualan tahunan lebih dari Rp. 2.500.000.000,00 (dua milyar lima ratus juta rupiah) sampai dengan paling banyak Rp. 50.000.000.000,00 (lima puluh milyar rupiah). (UU No. 20, 2008, bab IV pasal 6).

Pemberdayaan dan pengembangan Usaha Mikro merupakan upaya yang ditempuh pemerintah untuk mengatasi masalah pengangguran dan kemiskinan, karena pada dasarnya usaha mikro adalah usaha yang dimiliki dan dijalankan oleh penduduk miskin atau mendekati miskin. Usaha mikro sering disebut dengan usaha rumah tangga. (Rudjito, 2003)

Usaha mikro merupakan salah satu pilar utama ekonomi nasional karena dapat memperluas lapangan pekerjaan serta memberikan pelayanan ekonomi secara luas kepada masyarakat yang dapat berperan dalam proses pemerataan dan peningkatan pendapatan masyarakat, mendorong pertumbuhan ekonomi, sehingga mampu berperan mewujudkan stabilitas ekonomi nasional. Dengan demikian, usaha mikro memiliki peran yang sangat penting dalam perkembangan 
perekonomian Indonesia, peran-peran tersebut antara lain:

a. Usaha mikro merupakan pemain utama dalam kegiatan ekonomi di Indonesia.

b. Penyediaan kesempatan kerja.

c. Pemain penting dalam pengembangan ekonomi lokal dan pengembangan masyarakat.

d. Penciptaan pasar dan inovasi melalui fleksibilitas dan sensitivitas atas keterkaitan dinamis antar kegiatan perusahaan.

e. Memberikan kontribusi terhadap peningkatan ekspor non migas.

Perkembangan usaha mikro di Indonesia tidak terlepas dari berbagai masalah yang bukan hanya menurut jenis produk atau pasar yang dilayani saja, tetapi juga berbeda antar wilayah atau lokasi, antar sentra, antar sektor atau subsektor (jenis kegiatan) dan antar unit usaha. Namun demikian masalah dasar yang dihadapi oleh usaha mikro adalah:

a. Kesulitan Pemasaran; Pemasaran sering dianggap sebagai salah satu kendala yang kritis bagi perkembangan Usaha Mikro dan Kecil

b. Keterbatasan Finansial; Usaha mikro, khususnya di Indonesia menghadapi dua masalah utama dalam aspek finansial yakni mobilisasi modal awal (star-up capital) serta akses ke modal kerja

c. Keterbatasan Sumber Daya Manusia (SDM); Keterbatasan SDM juga merupakan salah satu kendala serius bagi banyak usaha mikro di Indonesia, terutama dalam aspekaspek entrepreneurship, manajemen, teknik produksi, pengembangan produk, engineering design, quality control, organisasi bisnis, akuntasi, data processing, teknik pemasaran, serta penelitian pasar.

d. Masalah Bahan Baku; Keterbatasan bahan baku (dan input-input lainnya) juga sering menjadi salah satu kendala serius bagi pertumbuhan output atau kelangsungan produksi bagi banyak Usaha Mikro di Indonesia. Keterbatasan bahan baku dikarenakan harga baku yang terlampau tinggi sehingga tidak terjangkau atau jumlahnya terbatas. 
e. Keterbatasan Teknologi; Usaha Mikro plafond yakni batasan perolehan di Indonesia umumnya masih pembiayaan yang diberikan oleh bank menggunakan teknologi lama atau tradisional dalam bentuk mesin-mesin tua atau alat-alat produksi yang sifatnya manual.(Tambunan, 2002)

\section{Pembahasan}

\section{Produk Pembiayaan Usaha Mikro BRI} Syariah

Produk Pembiayaan Usaha Mikro BRI Syariah merupakan produk pembiayaan usaha yang diperuntukkan bagi masyarakat menengah yang memiliki usaha kecil (mikro) untuk dijadikan tambahan modal seperti masyarakat yang memiliki usaha sembako, pakaian, pedagang pasar, masyarakat yang memiliki toko, bengkel dan lain sebaginya. (Qudrah, wawancara, 2015)

Produk Pembiayaan Usaha Mikro BRI Syariah bertujuan memberi pembiayaan mikro guna memenuhi kebutuhan modal dan juga investasi, untuk keperluan modal biasanya berjangka waktu 3 tahun sedangkan untuk keperluan investasi bisa berjangka waktu 5 tahun. Produk pembiayaan usaha mikro yang ada di PT. Bank BRI Syariah Kendari dibedakan menjadi tiga jenis produk dengan besaran syariah dan tenor yakni batas angsuran yang harus diberikan oleh nasabah pembiayaan mikro berbeda-beda.

Besarnya pembiayaan usaha mikro yang diberikan oleh BRI Syariah adalah sebesar Rp 5 juta sampai Rp 500 juta dengan margin beragam tergantung dari jumlah pembiayaan yang diberikan. Karena sistem pembiayaan mikro ini berbasis syariah, maka margin yang diberikan juga tidak pasti, tergantung kondisi nasabah dan masih bisa tawar-menawar. (Qudrah, wawancara, 2015)

Produk pembiayaan usaha mikro tersebut dapat terlihat dari table berikut:

Tabel 1: Produk Pembiayaan Mikro BRISyariah

\begin{tabular}{|c|c|c|}
\hline Produk & $\begin{array}{c}\text { Plafond } \\
\text { (juta) }\end{array}$ & Tenor \\
\hline Mikro 25iB & $5-25$ & $6-36$ \\
\hline Mikro 75iB & $5-75$ & $6-60^{*}$ \\
\hline Mikro 500iB & $755-500$ & $6-60^{*}$ \\
\hline $\begin{array}{l}\text { *Tenor dapat hingga 60 bulan dengan } \\
\text { ketentuan khusus }\end{array}$ \\
\hline
\end{tabular}

Sumber: hasil wawancara, diolah

a. Produk Mikro 25Ib; Produk Mikro 25iB merupakan produk pembiayaan pinjaman tanpa agunan dengan besaran plafon Rp. 5 juta s/d Rp. 25 juta lama masa tenor $6 \mathrm{~s} / \mathrm{d} 36$ bulan. 
b. Produk Mikro 75iB; Produk Mikro 75iB merupakan produk pembiayaan pinjaman dengan agunan bisa berupa Tanah dan Bangunan, Tanah Kosong, Kendaraan, Kios atau Deposito. Pada Produk Mikro 75iB, calon nasabah bisa melakukan pembiayaan sampai Rp. 75.000.000,- dengan pagu pinjaman Rp. 10.000.000,- s/d Rp. 75.000.000,- nasabah bisa memperoleh pinjaman sesuai kebutuhan dengan beberapa taraf pinjaman yang dapat diperoleh dengan jangka waktu peminjaman ditentukan oleh pihak bank yaitu: 12 bulan, 18 bulan, 24 bulan dan 36 bulan. Margin yang berlaku untuk jumlah pembiayaan yang berada di atas Rp 250 juta adalah 0.95 persen hingga 1 persen, sedangkan untuk pembiayaan yang berada di bawah Rp 250 juta, margin yang diberikan adalah 1,2 persen sampai 1,6 persen.

c. produk mikro 500iB; Produk Mikro 500iB merupakan produk pembiayaan pinjaman dengan agunan bisa berupa Tanah dan Bangunan, Tanah Kosong, Kendaraan, Kios atau Deposito dengan besaran plafon Rp. >75 juta s/d Rp. 500 juta dengan masa tenor $6 \mathrm{~s} / \mathrm{d} 60$ bulan.

\section{Persyaratan Pembiayaan Usaha Miko} BRI Syariah Cabang Kendari

Rifki Rahdian menyatakan bahwa semua jenis usaha yang tidak mengandung perjudian, tidak mengandung minuman keras serta semua usaha yang tidak diharamkan menurut syaria'at Islam adalah layak untuk dibiayai dengan persyaratan yang sudah ditetapkan oleh pihak bank berdasarkan produknya apakah M25iB, M75iB ataukah M500iB, sehingga jika plafon sudah melebihi limit 500 juta rupiah bukan lagi pembiayaan usaha mikro melainkan sudah usaha makro. (Rahdian, wawancara, 2015)

a. Persyaratan Umum: (1) Warga Negara Indonesia dan berdomisili di Indonesia, (2) Usia minimal 21 tahun/telah menikah untuk usia diatas >18 tahun, (3) Wiraswasta yang usahanya sesuai prinsip syariah, (4) Lama usaha calon nasabah: untuk Mikro 75iB dan Mikro 500iB, lama usaha minimal 2 tahun dan untuk Mikro 25iB, lama usahaa minimal 3 tahun, (5) Tujuan pembiayaan untuk kebutuhan modal kerja atau investasi, (6) Memiliki usaha tetap, (7) Jaminan atas nama milik sendiri atau pasangan atau orang tua atau anak kandung, (8) Biaya administrasi mengikuti syarat dan ketentuan yang berlaku.

b. Persyaratan Dokumen Umum; Persyaratan dokumen umum merupakan persyaratan dokumen nasabah yang harus dipenuhi oleh nasabah pada semua 
pembiayaan mikro BRISyariah baik Mikro 25iB, Mikro 75iB serta Mikro 500iB. Persyaratan tersebut adalah (1)

Foto copy KTP calon nasabah dan pasangan, (2) Kartu keluarga dan akta nikah, (3) Akta cerai / surat kematian (pasangan), serta (4) Surat izin usaha / surat keterangan usaha

Tabel 2: Persyaratan Dokumen Umum

\begin{tabular}{|l|r|r|r|}
\hline \multirow{2}{*}{ Persyaratan } & \multicolumn{3}{|c|}{ Nama Produk } \\
\cline { 2 - 4 } & $\begin{array}{c}\text { Mikro } \\
\text { 25iB }\end{array}$ & $\begin{array}{c}\text { Mikro } \\
\text { 75iB }\end{array}$ & $\begin{array}{c}\text { Mikro } \\
500 i B\end{array}$ \\
\hline $\begin{array}{l}\text { FC KTP Calon } \\
\text { Nasabah \& } \\
\text { Pasangan }\end{array}$ & $\checkmark$ & $\checkmark$ & $\checkmark$ \\
\hline $\begin{array}{l}\text { Kartu Keluarga } \\
\text { \& Akta Nikah }\end{array}$ & $\checkmark$ & $\checkmark$ & $\checkmark$ \\
\hline $\begin{array}{l}\text { Akta Cerai / } \\
\text { Surat Kematian } \\
\text { (Pasangan) }\end{array}$ & $\checkmark$ & $\checkmark$ & $\checkmark$ \\
\hline $\begin{array}{l}\text { Surat Izin } \\
\text { Usaha /Surat } \\
\text { Keterangan } \\
\text { Usaha }\end{array}$ & $\checkmark$ & $\checkmark$ & $\checkmark$ \\
\hline
\end{tabular}

c. Persyaratan Dokumen Khusus

Persyaratan dokumen umum merupakan persyaratan dokumen nasabah yang harus dipenuhi untuk produk pembiayaan Mikro 75iB dan Mikro 500iB. Persyaratn tersebut adalah Jaminan dan NPWP.

Tabel 3: Persyaratan Dokumen Khusus

\begin{tabular}{|c|c|c|c|}
\hline \multirow{3}{*}{ Persyaratan } & \multicolumn{3}{|c|}{ Nama Produk } \\
\cline { 2 - 4 } & Mikro & Mikro & Mikr \\
& $25 i B$ & $75 i B$ & o \\
& & & $500 i B$ \\
\hline
\end{tabular}

\begin{tabular}{|c|c|c|c|}
\hline Jaminan * & X & $\checkmark$ & $\checkmark$ \\
\hline NPWP ** & X & $\checkmark$ & $\checkmark$ \\
\hline \multicolumn{4}{|c|}{$\begin{array}{l}\text { *Tanah dan Bangunan, Tanah Kosong, } \\
\text { Kendaraan, Kios atau Deposito }\end{array}$} \\
\hline
\end{tabular}

\section{Akad Pembiayaan Usaha Mikro BRI}

\section{Syariah Cabang Kendari}

Salah satu fungsi bank adalah memberikan pembiayaan untuk memenuhi kebutuhan pihak-pihak yang memerlukan. Qudrah selaku staf Costumer Relation Officer menyatakan bahwa Salah satu program pembiayaan yang diberikan oleh BRI Syariah Cabang Kendari adalah pembiayaan untuk usaha mikro dengan menggunakan akad murabahah (Qudrah, 2015), wawancara) yakni suatu akad jual beli dimana harga jual sebesar harga perolehan ditambah keuntungan yang disepakati antara penjual dan pembeli. Murabahah dapat dilakukan berdasarkan pesanan ataupun tanpa pesanan. Murabahah berdasarkan pesanan berarti bank melakukan pembelian barang setelah ada pesanan dari nasabah.

Dalam kaitannya dengan pembiayaan usaha mikro, maka dalam hal ini BRI Syariah sebagai perwakilan untuk pembelian barang terhadap kebutuhan nasabah usaha mikro memiliki suatu tujuan untuk membiayai kebutuhan nasabah dalam hal pengadaan barang konsumsi 
seperti rumah, kendaraan atau barang produktif seperti mesin produksi, pabrik dan lain-lain. Kemudahan yang diberikan oleh BRI Syariah adalah nasabah dapat mengangsur pembayarannya dengan jumlah angsuran yang tidak akan berubah selama masa perjanjian. Kemudahan tersebut dapat memperingan beban yang harus ditanggung oleh pengusaha mikro.

\section{Prosedur Pembiayaan Usaha Mikro BRI Syariah Cabang Kendari}

Tugas pokok bank adalah menghimpun dana dari masyarakat dalam bentuk simpanan, dan menyalurkannya kembali kepada masyarakat dalam bentuk pembiayaan/kredit. Pembiayaan merupakan salah satu usaha BRI Syariah Cabang Kendari yang banyak diminati masyarakat, hal tersebut terlihat dari data penyaluran pembiayaan yang semakin meningkat setiap bulannya.

Dalam pemberian pembiayaan kepada nasabah, perlu adanya prosedur dan perjanjian antara pihak Bank (shahibul mall) dengan pihak nasabah. Perjanjian pembiayaan tersebut melibatkan empat hal, yaitu (l) bank sebagai pemberi pembiayaan, (2) nasabah sebagai pihak penerima pembiayaan, (3) Objek yang dituju untuk dibiayai, dan (4) jaminan yang diberikan oleh nasabah kepada bank.

Proses pemberian pembiayaan sangat memerhatikan aspek-aspek teknik administratif, yaitu:

a. Surat Permohonan Pembiayaan; Dalam surat permohonan berisi jenis pembiayaan yang diminta oleh nasabah, masa angsuran pembiayaan, limit/plafon yang diminta serta sumber pelunasan pembiayaan berasal dari mana. Disamping itu, suratpun dilampiri dengan dokumen pendukung, antara lain identitas pemohon, legalitas (akta pendirian/perubahan, surat keputusan menteri, perizinan-perizinan), bukti kepemilikan agunan (jika diperlukan).

b. Perjanjian Pembiayaan; Perjanjian dalam sebuah pembiayaan memiliki empat fungsi utama yaitu (1) perjanjian pembiayaan berfungsi sebagai dasar hukum bagi kedua belah pihak, (2) perjanjian pembiayaan merupakan dasar lahirnya perjanjian lainnya, perjanjian pembiayaan berfungsi untuk memperjelas hak kedua belah pihak, (4) perjanjian pembiayaan sebagai dasar lahirnya perjanjian asuransi.

Perjanjian pembiayaan antara nasabah dan kreditur dibuat dalam 
bentuk tertulis, namun sebelum perjanjian ditandatangani kedua belah pihak, ada beberapa tahapan yang akan dilalui calon nasabah yaitu (1) calon nasabah wajib membuat surat permohonan pemberian pembiayaan kemudian diajukan kepada pihak bank, (2) jika surat permohonan pembiayaan telah diterima Bank, Bank melakukan pemerikasaan yaitu dengan melihat apakah pembiayaan yang dimohonkan masuk dalam pasar sasaran dan KRD (Kriteria Risiko Yang Dapat Dilayani) serta apakah telah memenuhi kelengkapan administrasi yang dibutuhkan untuk mengajukan permohonan pembiayaan, (3) apabila surat permohonan pembiayaan yang diajukan masuk kategori diatas, maka bank akan melakukan penelitian dan analisis dengan cara melakukan kunjungan atau melihat secara langsung kegiatan usaha yang dijalankan calon nasabah, kemudian bank melakukan wawancara dengan calon nasabah, (4) apabila penelitian dan analisis telah dilakukan oleh pihak bank, kemudian dilakukan pemutusan pembiayaa oleh pejabat pembiayaan, bank kemudian mengeluarkan surat Penawaran Putusan Pembiayaan (SP3) yang berisi tentang persyaratan pembiayaan yaitu meliputi jumlah pembiayaan, jangka waktu pembiayaan dan lain-lain, surat ini kemudian diajukan kepada calon nasabah, apabila calon nasabah menyetujui maka dibuat perjanjian sesuai dengan persyaratan yang telah disepakati.

Dari keempat fungsi perjanjian di atas, akan melahirkan suatu kesepakatan antara pihak kreditur dan nasabah dimana calon nasabah harus memenuhi persyaratan yang diberikan pihak bank selaku kreditur. Persyaratan tersebut merupakan persyaratan standar dan baku yang disesuaikan dengan jenis usaha dan skim yang diberikan, karena setiap jenis pembiayaan bisa berbeda persyaratannya. Untuk menjadi seorang nasabah dalam pembiayaan usaha mikro dengan akad murabahah ada beberapa hal yang harus dimiliki oleh nasabah sehingga pihak Bank akan mencairkan dana untuk pengembangan usahanya dengan catatan (l) memiliki usaha yang dikembangkan dan sudah berjalan selama dua tahun, (2) tempat usaha harus menetap tidak boleh berpindah-pindah tempat, (3) melengkapi persyaratan yang diajukan oleh pihak Bank.

c. Proses Evaluasi Pengajuan Pembiayaan; Dalam penilaian suatu permohonan 
pembiayaan, BRI Syariah Cabang Kendari berpegang pada prinsip kehatihatian serta aspek lainnya sehingga diharapkan dapat diperoleh hasil yang cermat dan akurat. Sebelum persetujuan pembiayaan diputuskan, BRI Syariah Cabang Kendari melakukan beberapa proses penilaian sebagai bentuk evaluasi terhadap pengajuan pembiayaan.

Setelah berkas pembiayaan dari nasabah diterima, yang akan dilakukan pihak BRI Syariah Cabang Kendari adalah (1) melacak track record nasabah melalui data yang ada di BI sehingga akan ketahuan apakah calon nasabah tersebut termasuk nasabah bermasalah atau tidak, (2) melakukan perhitungan perputaran usaha sehingga akan ketahuan berapa limit yang mampu dibayarkan, (3) menentukan plafon pembiayaan yang akan diberikan, (4) melihat perkembangan ekonomi makro, karena bisa jadi jika perkembangan ekonomi yang tidak baik akan berpengaruh langsung terhadap perkembangan usaha calon nasabah, (5) melihat jaminan yang dapat digunakan sebagai ukuran batas maksimum pemberian pembiayaan. (Rahdian, 2015)
Dari penuturan informan tersebut, tahapan proses evaluasi pemberian pembiayaan mikro BRISyariah Cabang Kendari adalah:

1) Penetapan pasar sasaran; Sasaran nasabah pembiayaan usaha mikro adalah kelompok ataupun individu dalam suatu industri, segmen ekonomi, pasar, atau suatu daearah geografis yang memiliki ciri-ciri tertentu yang diinginkan dan dipandang perlu untuk pengalokasian usaha dan biaya pemasaran dalam mencari peluangpeluang bisnis baru/perusahaan bisnis. Penetapan pasar sasaran bertujuan agar pemberian pembiayaan dapat dilakukan secara lebih terarah dan sesuai dengan sumber daya yang dimiliki BRI Syariah Cabang Kendari sehingga dapat memberikan manfaat yang optimal bagi kedua belah pihak.

2) Proses pemberian putusan pembiayaan; Proses pemberian pembiayaan merupakan tahapantahapan yang dilalui oleh nasabah maupun kreditur sehingga pembiayaan tersebut dapat diberikan. Tahapan proses pemberian putusan pembiayaan 
tersebut adalah (l) prakarsa dan dapat berperan dalam proses pemerataan dan permohonan pembiayaan, (2) analisis peningkatan pendapatan masyarakat, dan evaluasi pembiayaan, (3) negosiasi mendorong pertumbuhan ekonomi, sehingga pembiayaan, (4) penetapan struktur mampu berperan mewujudkan stabilitas dan tipe pembiayaan (5) rekomendasi ekonomi nasional, oleh karenanya dan pemberian putusan pembiayaan, pemberdayaan dan pengembangan Usaha (6) kelengkapan paket pembiayaan, Mikro merupakan upaya yang ditempuh serta (7) pemberian putusan pemerintah untuk mengatasi masalah pembiayaan.

3) Proses realisasi pembiayaan; Realisasi pembiayaan BRI Syariah Cabang Kendari akan melalui beberapa tahapan yaitu pengajuan pembiayaan, pemberian putusan pembiayaan, (3) pembuatan perjanjian pembiayaan (4) dokumen dan administrasi pembiayaan (5) persetujuan pencairan pembiayaan, pembinaan dan pengawasan.

\section{Risiko Pembiayaan Usaha Mikro BRI} Syariah Cabang Keendari

Usaha Mikro merupakan usaha produktif milik orang perorangan dan/atau badan usaha perorangan yang merupakan salah satu pilar utama ekonomi nasional karena dapat memperluas lapangan pekerjaan serta memberikan pelayanan ekonomi secara luas kepada masyarakat yang pengangguran dan kemiskinan.

Perkembangan usaha mikro di Indonesia tidak terlepas dari berbagai masalah yang diantaranya adalah keterbatasan dalam hal financial baik untuk modal maupun pengembangan usaha. Untuk menjawab itu semua, maka bank hadir dengan salah satu fungsi utamanya menyalurkan dana kepada masyarakat melalui pembiayaan.

Dalam penyaluran dananya, bank tidak bisa lepas dari risiko yang mungkin muncul akibat pembiayaan. Risiko pembiayaan yang diperuntukkan bagi usaha tentunya memiliki risiko sangat tinggi yang bisa ada akibat internal nasabahnya ataupun keadaan ekonomi yang sedang lesu sehingga menurunkan minat beli masyarakat. Dalam hal penyaluran pembiayaan untuk usaha mikro, banyak hal yang harus diperhatikan sehingga nasabah dapat terus membayar 
angsuran pembiayaannya. Terkadang ada nasabah yang menurut penilaian kita mampu untuk membayar angsurannya, tetapi mungkin karena ada keperluan lain sehingga tidak bisa melunasinya. Atau ada pula nasabah yang tidak mampu membayar angsuran dikarenakan menurut nasabah usahanya lagi sepi dari pembeli sehingga tidak memiliki kemampuan untuk membayar pembiayaannya sesuai dengan kesepakatan. (Rahdian, 2015)

Secara spesifik risiko yang timbul merupakan akibat dari fenomena yang terjadi, dimana risiko pembiayaan usaha bisa terjadi karena beberapa hal misalkan nasabah pindah alamat atau bahkan data yang diberikan nasabah fiktif, ketidak mampuan nasabah untuk membayar pembiayaannya hal tersebut karena plafon pembiayaan yang diberikan melebihi kapasitas kemampuan nasabah, dampak ekonomi masyarakat juga bisa berpengaruh terhadap kemampuan bayar nasabah seperti usaha tambang atau ada juga yang penggunaan dananya tidak sesuai dengan peruntukkan sewaktu melakukan akad pembiayaan seperti pada saat pengajuan ushanya adalah sembako tetapi dialihkan pada usaha bengkel atau bahkan sewaktu pengajuannya untuk usaha tetapi digunakan untuk membangun ataupun memperbaiki rumah. (Rahdian, 2015)

Dengan berbagai fenomena yang terjadi, risiko pimbiayaan terutama pada program pembiayaan usaha mikro pada dasarnya tidak bisa dihindari seutuhnya. Namun demikian pihak bank harus mampu memiliki strategi untuk mencegah ataupun hanya untuk meminimalisir risiko yang mungkin terjadi sehingga tidak berdampak kerugian yang tidak dapat ditanggung oleh bank tersebut.

\section{Kesimpulan}

1. Pengertian usaha mikro dan kecil dapat dibedakan berdasarkan indikator dari usaha tersebut, antara lain (l) mengenai jumlah kekayaan, seperti uang tunai, persediaan, tanah, mesin untuk produksi dan sumber daya lainnya yang dimiliki, (2) jumlah besarnya penyertaan yang dianggap sebagai modal kerja, (3) jumlah total penjualan dalam setahun, (4) jumlah pegawai yang dipekerjakan berdasarkan jenis dan sifat usaha yang dijalani

2. Pembiayaan Usaha Mikro BRI Syariah merupakan produk pembiayaan usaha yang diperuntukkan bagi masyarakat menengah yang memiliki usaha kecil (mikro) dengan tujuan guna memenuhi kebutuhan modal dan juga investasi 
seperti usaha sembako, pakaian, pedagang pasar, masyarakat yang memiliki toko, bengkel dan lain sebaginya.

3. Pembiayaan Usaha Mikro BRI Syariah dibedakan menjadi tiga produk, yaitu

a. Produk Mikro 25Ib; Produk Mikro $25 i B$ merupakan produk pembiayaan pinjaman tanpa agunan dengan besaran plafon Rp. 5 juta s/d Rp. 25 juta dengan jangka waktu peminjaman $6 \mathrm{~s} / \mathrm{d} 36$ bulan.

b. Produk Mikro 75iB; Produk Mikro $75 i B$ merupakan produk pembiayaan pinjaman dengan agunan bisa berupa tanah dan bangunan, tanah kosong, kendaraan, kios atau deposito. Pada Produk Mikro 75iB, besaran plafon Rp. 10 juta s/d Rp. 75 juta dengan jangka waktu peminjaman $12 \mathrm{~s} / \mathrm{d} 36$ bulan.

c. produk mikro 500iB; Produk Mikro 500iB merupakan produk pembiayaan pinjaman dengan agunan bisa berupa tanah dan bangunan, tanah kosong, kendaraan, kios atau deposito dengan besaran plafon Rp. $>75$ juta s/d Rp. 500 juta jangka waktu peminjaman 6 s/d 60 bulan.

\section{DAFTAR PUSTAKA}

Adi, M. Kwartono. Analisis Usaha Kecil dan Menengah, Cet. l. Yogyakarta: C.V Andi Offset, 2007
Amalia, Euis. Keadilan Distributif Dalam Ekonomi Islam. Jakarta: Rajawali Press, 2009

Antonio, Muhammad Syafi'i. Bank Syariah Dari teori Ke Praktik. Jakarta: Gema Insani. 2001

Capra, M. Umer. Sistem Moneter Islam. Edisi terjemah. Jakarta: Gema Insani Press $\&$ Tazkia Cendekia, 2000

Djumhana. Hukum Perbankan Di Indonesia. Bandung: Citra Aditya Bakti, 2000

Hafsah, Muhammad Jafar. Kemitraan Usaha Konsepsi Dan Strategi. Jakarta: Pustaka Sinar Harapan, 2000

Kasmir. Bank dan Lembaga Keuangan Lainnya. Jakarta: PT Raja Grafindo Persada, 2005

Lubis, Suhrawardi K. Hukum Ekonomi Islam. Jakarta: Sinar Grafika, 2004

Muhammad, Manajemen Pembiayaan Bank Syaria. Yoyakarta: UUP AMP YKPN 2005

Nitisusastro, Mulyadi. Kewirausahaan dan Manajemen Usaha Kecil. Bandung: Alfabeta, 2009

Sinungan, Muchdarsyah. Manajemen Dana Bank. Jakarta: PT. Bumi Aksara, 2000

Tambunan, Thulus. Usaha Kecil Dan Menengah Di Indonesia, Beberapa Isu Penting. Jakarta: Salemba Empat, 2002

Triandaru, Sigit Dan Totok Budisantoso. Bank Dan Lembaga Keuangan Lain. Jakarta: Salemba Empat, 2006

Republik Indonesia. Undang-undang perbankan No.10 Tahun 1998, Cet 1. Jakarta: Sinar Grafika, 2001

Republik Indonesia, Undang-Undang Nomor 20 Tahun 2008 Tentang Usaha Mikro, Kecil, Dan Menengah

Rudjito. 2003. "Peran Lembaga Keuangan Mikro dalam Otonomi Daerah Menggerkan Ekonomi Rakyat dan Menanggulangi Kemiskinan" dalam Jurnal Ekonomi Rakyat Th.ll-No.l-Maret 2003 